\title{
Makna pernikahan usia dini bagi orang tua di Nagari Tapan, Kecamatan Basa Ampek Balai Tapan
}

\author{
Septra Yodi*, Budijanto*, Singgih Susilo* \\ * Department of Geography, Faculty of Social Science, Universitas Negeri Malang, \\ Indonesia
}

\begin{tabular}{l}
\hline \hline ARTICLES INFO \\
\hline Profil Articles: \\
Sent: 31-1-2020 \\
Approved: $19-5-2020$ \\
Published: 30-6-2020 \\
\hline
\end{tabular}

Key words:

makna pernikahan usia dini, orang tua, Nagari Tapan

\begin{abstract}
Indonesia has a law governing marriage, the Law number 1 of 1974 concerning Marriage stipulates that a marriage can be performed if the age of the groom is over 19 years and the age of the bride is over 16 years. But early marriage in Nagari Tapan, Basa Ampek Balai Tapan Sub-district happened every year. The triggering factors for early marriage were promiscuity, economy and the mass media. This research was conducted to reveal the meaning of early marriage for parents. This study used qualitative research with a Geographic spatial approach and phenomenology approach from Alfred Schutz's proposition to identify because motives and the in-order-to motives in conducting an early marriage which produces a meaning. The data were analyzed through several studies, namely: preparatory research, research, in the field, and data analysis (data reduction, display data, and verification data). The results shows that the meaning of early marriage in Nagari Tapan, Basa Ampek Balai Tapan Sub-district, found three meanings of early marriage; early marriage is agreed to avoid family's shame, early marriage as an effort to help the economy, and early marriage as a rescue effort.
\end{abstract}

Indonesia memiliki Undang-Undang yang mengatur tentang pernikahan yaitu Undang-Undang pernikahan nomor 1 tahun 1974 menjelaskan bahwa pernikahan dapat dilakukan apabila usia laki-laki berada diats 19 tahun dan usia perempuan berada diatas 16 tahun. Namun pernikahan usia dini di Nagari Tapan, Kecamatan Basa Ampek Balai Tapan selalu terjadi setiap tahun. Faktor penyebab terjadinya pernikahan usia dini yaitu factor pergaulan bebas, perekonomian, dan media massa. Penelitian ini dilakukan untuk mengungkapkan makna pernikahan usia dini bagi orang tua. Penelitian ini menggunakan jenis penelitian kualitatif dengan pendekatan keruangan Geografi. Penelitian kualitatif ini menggunakan pendekatan fenomenologi proposisi Alfred Schutz untuk mengetahui motive sebab (because motives) dan motif tujuan (in order to motives) melakukan pernikahan usia dini yang menghasilkan sebuah makna. Data dianalisis melalui beberapa tahap yaitu: tahap persiapan penelitian, tahap penelitian dilapangan, dan tahap analisis data (reduksi data, display data, dan tahap verifikasi data). Hasil penelitian menunjukkan bahwa makna pernikahan usia dini bagi orang tua di Nagari Tapan, Kecamatan Basa Ampek Balai Tapan ditemukan tiga pemaknaan pernikahan dini yaitu: pernikahan usia dini sebagai menghindar malu, pernikahan usia dini sebagai upaya membantu perekonomian, dan pernikahan usia dini sebagai upaya penyelamatan.

This is an open access article under the CC-BY-SA license

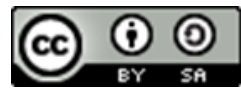


Jurnal Pendidikan Geografi:

Kajian, Teori, dan Praktik dalam Bidang Pendidikan dan Ilmu Geografi

Volume 25, Nomor 2, Jun 2020, Hal 128-144

\section{Correspondent Author:}

Septra Yodi

Department of Geography

Universitas Negeri Malang

J1. Semarang 5 Malang, 65145

E-mail: yodiseptra@gmail.com

\section{PENDAHULUAN}

Pernikahan memiliki aturan yang menjadi landasan utama dilaksanakan sebuah pernikahan di berbagai negara termasuk Indonesia. Indonesia memiliki Undang-Undang yang mengatur tentang pernikahan yaitu Undang-Undang pernikahan nomor 1 tahun 1974 bahwa pernikahan dapat dilakukan apabila usia laki-laki berada diats 19 tahun dan usia perempuan berada diatas 16 tahun. Undang-Undang pernikahan ini mengandung prinsip yang sangat tegas bahwa calon suami istri harus memiliki jiwa dan mental yang masak agar dalam sebuah pernikahan tidak berakhir dengan perceraian dan juga agar mendapatkan keturunan yang bagus. Jika pernikahan dilakukan dibawah 19 tahun untuk umur laki-laki dan 16 tahun untuk umur perempuan akan berdapak terhadap fisik dan mental mereka.

Jika pernikahan yang dilakukan ketika usia anak perempuan dibawah 16 tahun dan anak laki-laki dibawah 19 tahun dikatakan sebagai pernikahan usia dini. Pernikahan usia dini adalah pernikahan yang dilakukan oleh seorang laki-laki dan perempuan di usia antara 10-19 tahun dimana di usia itu seorang individu masih dalam masa puberitas dan pola fikir yang belum matang, tapi dalam pernikahan usia dini yang menjadi sorotan usia adalah seorang perempuan (Pohan, 2017; Susilo, 2017; Montazeri, 2016; UNFPA, 2012 ; dan UNICEF, 2014).

Undang-Undang Pernikahan tahun 1974 pasal 6 ayat 2 menyatakan bahwa "pernikahan yang dilakukan dibawah usia 21 tahun harus mendapatkan izin dari kedua orang tua". Undang-Undang tersebut menjelaskan secara tegas bahwa pernikahan dapat dilakukan apabila laki-laki dan perempuan berusia diatas 21 tahun. Laki-laki dan perempuan yang masih berumur dibawah 21 tahun digolongkan kedalam remaja dan semua tindakan/perbuatan yang dilakukan oleh mereka merupakan tanggung jawab orang tua.

Secara biologis, kematangan reproduksi remaja akhir berada di usia 22 tahun, sehingga menikah dini rentan terjadinya infeksi. Secara psikologis, emosi remaja masih dalam tahap perkembangan sehingga pernikahan pada remaja akan membentuk kepribadian yang belum matang dan menyebabkan terjadinya pertengkaran karena emosi yang tidak terkontrol (Oktaviani dkk, 2018). Pernikahan usia dini yang dilakukan oleh seorang perempuan akan berdampak terhadap perkembangan kognitif, emosi, dan sosial. Pertama, perkembangan kognitif. Pada remaja awal, perkembangan otak yang belum matang dapat membuat perasaan atau emosi mengalahkan akal sehat alasan yang memungkinkan remaja untuk membuat pilihan yang tidak bijaksana seperti penyalahgunaan narkoba dan melakukan aktivitas seksual berisiko (Oktaviani dkk, 2018).

Kedua, perkembangan emosi. Oktaviani (2018) mengungkapkan tentang emosionalitas laki-laki dan perempuan, bahwa usia remaja merupakan usia kelabilan pada emosinya yang terkadang berakibat kepada keputusan untuk menikah dengan tergesa-gesa tanpa melalui pertimbangan yang matang. Remaja, selalu berkhayal tentang sesuatu yang enak-enak dan menyenangkan serta terkadang tidak realistis. Emosi yang 
Jurnal Pendidikan Geografi:

Kajian, Teori, dan Praktik dalam Bidang Pendidikan dan Ilmu Geografi

Volume 25, Nomor 2, Jun 2020, Hal 128-144

tidak stabil akan berdampak terhadap tingginya gtingkat perceraian dan kekerasan dalam rumah tangga. Remaja yang tidak memiliki emosi yang stabil akan cenderung mengambil keputusan yang secara spontanitas tanpa memikir dampak dari keputusan yang diambil.

Ketiga, perkembangan sosial. Menurut Yulianti (2010) menjelaskan bahwa sifatsifat keremajaan ini (seperti, emosi yang tidak stabil, belum mempunyai kemampuan yang matang untuk menyelesaikan konflik-konflik yang dihadapi, serta belum mempunyai pemikiran yang matang tentang masa depan yang baik) sangat memengaruhi perkembangan psikososial anak dalam hal ini kemampuan konflik pun, usia itu berpengaruh. Secara sosial, remaja yang menikah diusia muda akan megalami kegoncangan sosial dimana dia akan memiliki berbagai peran dan status sosial yang belum siap dijalaninya.

Pembatasan usia pernikahan merupakan salah satu bentuk upaya untuk menanggulangi pernikahan usia dini yang tinggi di Indonesia. Berdasarkan data penelitian Pusat Kajian Gender dan Seksualitas Universitas Indonesia tahun 2015, didapatkan angka perkawinan dini di Indonesia peringkat kedua teratas setelah Negara Kamboja di kawasan Asia Tenggara dan diurutan ke 37 dari 158 Negara di dunia (Susilo, 2017). Perserikatan Bangsa-Bangsa (PBB) pada tahun 2015 mengeluarkan program baru yang disebut Sustainable Development Goals (SDGs) dan berlaku bagi negara-negara maju dan berkembang untuk 15 tahun ke depan (Nirmala, 2015). Terdapat 17 poin tujuan SDGs, salah satunya pada poin ke-5 tentang kesetaraan Gender. Penjelasan dari poin tersebut yaitu, "mencapai kesetaraan gender dan memberdayakan kaum ibu dan perempuan" (Stevance, dkk, 2015). Target dari Kesetaraan gender tersebut salah satunya adalah menghilangkan segala bentuk praktik berbahaya, seperti pernikahan anak-anak, usia dini dan paksaan, serta sunat perempuan.

Fakta di lapangan menunjukkan bahwa kebijakan yang telah di tetap dalam Undang-undang perkawinan tidak terlalu banyak memberi pengaruh terhadap keberlangsungan pernikahan usia dini di Nagari Tapan, karena pernikahan usia dini terjadi setiap tahunnya. Berdasarkan hasil observasi dengan petugas pencacatan tentang permintaan surat Na pernikahan di Nagari Tapan, mengatakan bahwa pernikahan usia dini terjadi akibat hamil diluar nikah dan hasil penggerebekan oleh masyarakat sekitar. Pernikahan usia dini melalui hasil penggerebekan sekitar $20 \%$, hamil diluar nikah yaitu $30 \%$, dan putus sekolah 50\%. Penggrebekan yang di maksud yaitu terdapat laki-laki dan perempuan di dalam satu rumah tanpa kehadiran kedua orangtua.

Masyarakat Nagari Tapan merupakan masyarakat yang memiliki jiwa sosial yang tinggi dituang dalam sebuah semboyan "Barek samo dipikua, ringan samo di jinjiang". Semboyan itu menjelaskan bahwa setiap yang berat sama-sama dipikul dan setiap yang ringan sama-sama dijinjing. Semboyan tersebut yang membuat masyarakat Nagari Tapan tidak memiliki jarak antara yang kaya dengan yang miskin. Semboyan tersebut telah dipegang teguh semenjak Ninik Moyang masyarakat Nagari Tapan. Selain itu, masyarakat Nagari Tapan memiliki semboyan adat yaitu "Adat basandi syara', syara'basandi kitabullah, syara'mangato adat mamakai”. Semboyan itu menjelaskan bahwa adat itu bersandar kepada agama, agama bersandar pada kitab Allah (Alqur'an), agama mengatakan dan adat yang memakai. Namun, kenyataannya masih ada masyarakat Nagari Tapan yang tidak menjalankan semboyan adat tersebut sehingga banyak anak remaja melakukan zina dan digerebek yang berdampak langsung pada pernikahan usia dini.

Pernikahan usia dini di Nagari Tapan rata-rata terjadi pada anak remaja yang masih duduk dibangku Sekolah Menengah Pertama/Sederajat (SMP/MTSN) dan Sekolah 
Jurnal Pendidikan Geografi:

Kajian, Teori, dan Praktik dalam Bidang Pendidikan dan Ilmu Geografi

Volume 25, Nomor 2, Jun 2020, Hal 128-144

Menengah Atas/Sederajat (SMA/SMK). Usia sekolah tersebut dimana anak-anak masih memiliki psikologi yang labil dan mencari jati diri serta sikap ingin tahu yang kuat. Sikap yang labil dan keingin tahuan yang tinggi membuat para remaja tersebut menggunakan teknologi sesuai dengan apa yang mereka inginkan. Sehingga kebanyakan para remaja tersebut banyak membuka situs porno yang kemudian mereka melakukan adegan yang sama kepada lawan jenisnya tanpa memikirkan dampak dari tindakan yang dilakukannya. Tindakan yang dilakukan mereka tersebut memberikan dampak yang sangat besar terjadinya pernikahn usia dini.

Tinggi rendahnya penduduk suatu daerah dipengaruhi oleh tingkat pendidikan, pemilikan lahan, dan intensitas kerja. Davis dan Blake (dalam Budijanto, 2011) menyatakan bahwa tinggi rendahnya penduduk dipengaruhi oleh banyak faktor, yaitu: pendidikan wanita, pendapatan keluarga, pemilikan lahan, keikutsertaan ibu dalam kegiatan ekonomi (pekerjaan) dan variable antar (intermediate variable) seperti umur perkawinan, penggunaan metode kontrasepsi, lama periode reproduksi dan mortalitas bayi. Salah satu buku Davis dan Blake yang berjudul "The social Structure of Fertility: An Analytical Framework"menyatakan bahwa proses reproduksi seorang perempuan usia subur melalui tiga tahap, yaitu: hubungan kelamin, konsepsi, kehamilan, dan kelahiran.

Pernikahan usia dini berkaitan dengan hubungan sebab dan akibat terjadinya tindakan yang dilakukan oleh seorang individu, sedangkan Alfred Schutz juga mengatakan bahwa tindakan yang dilakukan oleh seorang individu tidak terlepas dari "motif tujuan" (in order motives) dan juga "motif sebab" (because motives). Melalui penelitian ini, makna pernikahan dini bagi orang tua dapat dideskripsikan secara komprehensif.

\section{METODE}

Penelitian dilakukan di Nagari Tapan, Kecamatan Basa Ampek Balai Tapan, Kabupaten Pesisir Selatan, Provinsi Sumatera Barat. Penelitian ini dilaksanakan dari tanggal 14 November - 25 November 2019. Penelitian ini menggunakan pendekatan keruangan Geografi dengan jenis penelitiannya kualitatif. Penelitian kualitatif adalah riset yang bersifat deskriptif dan cenderung menggunakan analisis induktif. Penelitian kualitatif lebih menonjolkan proses dan pemaknaan (perspektif subyek) dalam makna pernikahan usia dini. Penelitian kualitatif ini menggunakan perspektif fenomenologi menurut Alfred Schutz. Perspektif fenomenologi merupakan metode sosial dalam pengamatan terhadap pola perilaku seseorang sebagai aktor sosial dalam masyarakat. Perspektif fenomenologi memiliki kemampuan dalam mengkaji makna pernikahan usia dini bagi orang tua sebagai realita subjektif (Susilo, 2011). Pendekatan fenomenologi yang digunakan dalam penelitian ini dikembangkan oleh Alfred Schutz yang menggabungkan konsep vesrtehen (Weber) dengan konsep lebenswelt (Husserl). Alfred Schutz mengkoreksi konsep yang disampaikan oleh Weber bahwa motif tindakan seseorang bukan hanya tentang "supaya" atau "in order to motives" tetapi juga karena adanya "motif sebab" atau "because motives" yang mengikuti di dalamnya. Alfred Schutz menjelaskan bahwa dalam kehidupan sehari-hari manusia lebih merupakan suatu realitas yang praktis atas motif "supaya" dan "sebab". Hal inilah yang menjadi sikap dan tindakan alami manusia, yaitu diatur oleh motif supaya (in order motives) dan motif sebab (because motives) (Susilo, 2017; Fatchan 2013:98).

Subyek penelitian dalam penelitian ini berjumlah 14 informan terdiri dari orang tua pelaku pernikahan dini. Alur dalam wawancara yang digunakan adalah ketika jawaban dari informan sama (jenuh) maka berhenti melakukan wawancara dan jika 
Jurnal Pendidikan Geografi:

Kajian, Teori, dan Praktik dalam Bidang Pendidikan dan Ilmu Geografi

Volume 25, Nomor 2, Jun 2020, Hal 128-144

belum menemukan jawaban sama dari informan, maka wawancara akan berlanjut. Penggalian informasi pada subyek menggunakan metode observasi partisipasi dan wawancara mendalam. Penelitian ini menggunakan teknik analisis yang dikembangkan oleh Miles dan Huberman "yaitu menggunakan analisis model interaktiv". Model analisis ini berlangsung bersamaan saat pengumpulan data. Beberapa tahapannya yaitu: tahap persiapan penelitian, tahap penelitian dilapangan, dan tahap analisis data (reduksi data, display data, dan tahap verifikasi data).

\section{HASIL DAN PEMBAHASAN}

Pernikahan usia dini adalah pernikahan yang dilakukan oleh seorang laki-laki dan perempuan di usia antara 10-19 tahun dimana di usia itu seorang individu masih dalam masa puberitas dan pola fikir yang belum matang, tapi dalam pernikahan usia dini yang menjadi sorotan usia adalah seorang perempuan (Pohan, 2017 dan Susilo, 2017). Pemaknaan pernikahan usia dini bagi orang tua di Nagari Tapan terbagi menjadi tiga yaitu: Pernikahan Usia Dini Sebagai Upaya Menghindari Malu sebanyak 35,7 persen, Pernikahan Usia Dini Sebagai Upaya Membantu Perekonomian sebanyak 28,6 persen, dan Pernikahan Usia Dini Sebagai Upaya Penyelamatan sebanyak 35,7 persen. Berikut ini penjelasan terperinci tentang makna pernikahan yang dilakukan oleh orang tua yang ada di Nagari Tapan.

\section{Pernikahan Usia Dini Sebagai Upaya Menghindari Malu}

Setiap subyek penelitian memaknai tentang pernikahan usia dini merupakan bentuk usaha untuk menghindari malu keluarga dari masyarakat. Hampir sebagian besar subyek yang diteliti memberikan jawaban yang sama ketika ditanya alasan menikahkan anaknya di usia dini. Subyek yang memaknai pernikahan usia dini sebagai upaya menghindari malu yaitu RD, sebagaimana dirinya mengungkapkan bahwa:

\footnotetext{
... "Anak saya yang bungsu bernama NS, dia saya nikahkan di usia 16 tahun. Saya menikahkannya karena sudah hamil duluan, karena sudah hamil duluan saya tidak bisa menolak untuk menikahkannya. Bagi saya menikahkannya sama saja menghindarkan rasa malu keluarga kami dari masyarakat" ... (Wawancara, tanggal 14 November 2019)
}

Ungkapan RD tersebut dapat dipahami bahwa makna menikahkan anaknya di usia dini yaitu untuk menghindarkan rasa malu keluarganya dari masyarakat sekitar. RD menikahkan anak bungsunya yang bernama NS saat berusia 16 tahun. RD menjelaskan bahwa laki-laki yang menghamili NS itu bukan laki-laki pilihan RD. Laki-laki itu pilihan NS, bahkan saat mereka pacaran RD pun tidak tahu tentang laki-laki itu.

Setelah NS hamil, NS baru memperkenalkan OR kepada RD. Melihat nasi yang sudah menjadi bubur ibarat pepatah, mau tidak mau NS harus dinikahkan. Melihat perut NS semakin hari semakin membesar membuat RD tidak tega ketika anak bungsunya melahirkan nanti cucunya tidak memiliki seorang ayah. Kekhawatiran itu membuat RD menikahkan NS. Selain dari itu alasan lain yang diungkapkan oleh RD yaitu jika NS tidak dinikahkan, maka tidak ada lagi yang mau menikah dengan Novi melihat kondisi NS yang sudah hamil. berikut:

RD memiliki harapan yang sangat besar atas pernikahan anak bungsunya sebagai

... "Saya sangat bahagia dan lega melihat NS sudah menika karena bisa membebaskan keluarga kami dari bahan gunjingan masyarakat sekitar rumah saya. Masyarakat kami akan terus menjadi kelaurga kami sebagai bahan gunjingan 
Jurnal Pendidikan Geografi:

Kajian, Teori, dan Praktik dalam Bidang Pendidikan dan Ilmu Geografi

Volume 25, Nomor 2, Jun 2020, Hal 128-144

sampai menikah. Setelah menikah masyarakat kami tidak akan pernah lagi membahas tentang hamil diluar nikah" ... (Wawancara 14 November 2019)

Ungkapan RD tersebut dapat diketahui bahwa motif tujuan (in order to motive) menikahkan NS di usia dini yaitu untuk menghindari gunjingan masyarakat terhadap keluarganya. Saat sekarang ini NS sudah berusia 25 tahun dan sudah memiliki 2 orang anak. Anaknya pertama bernama SO lahir pada tanggal 25 April 2012. Anak pertama NS ini merupakan anak hasil dari hamil diluar nikah. Anak kedua NS bernama KA lahir pada tanggal 09 Januari 2018. Anak kedua NS ini merupakan anak yang bersih karena setelah anak pertama NS lahir dia dikahkan kembali agar keturunan berikutnya menjadi anak yang bersih.

Pandangan RD sama dengan IN tentang menikahkan anaknya di usia dini yaitu untuk menghindari malu keluarga dari masyarakat sehingga tidak bisa menolak melakukan pernikahan. Hal ini terungkap dari perkataan informan berikut ini:

\begin{abstract}
... "Anak saya menikah saat itu usia 14 tahun. Saya menikahkannya dengan alasan hamil diluar nikah. Hamil diluar nikah sesuatu hal yang sangat tidak terpuji dan membuat nama keluarga tercoreng di masyarakat. Melihat perut anak saya yang sudah memasuki 5 bulan dan tidak bisa diembunyikan, maka harus dinikahkan. Menikahkan VJ sama saja menghindari malu keluarga dari masyarakat sekitar" ... (Wawancara, tanggal 14 November 2019)
\end{abstract}

Ungkapan IN tersebut dapat dipahami bahwa memaknai pernikahan usia dini yaitu upaya menghindari malu keluarga dari masyarakat. Motif sebab (because motives) IN menikahkan anaknya di usia dini karena pergaulan bebas mengakibatkan VJ hamil diluar nikah dengan kata lain Married By Accident (MBA). Motif tujuan (in order to motives) IN menikahkan anaknya di usia dini yaitu gunjingan masyarakat sekitar. Jika gunjingan ini tidak dihindari akan membuat keluarga IN tidak akan merasa nyaman dalam mengikuti kegiatan masyarakat. Pernikahan usia dini di desanya bukan sesuatu hal yang tabu lagi, apalagi pernikahan usia dini dilakukan karena hamil diluar nikah.

Ungkapan IN tersebut juga menjelaskan bahwa menikahkan anak di usia 14 tahun bukan sesuatu hal yang wajar, karena hamil diluar nikah akibat pergaulan bebas maka menikahkan di usia 14 tahun itu merupakan sesuatu hal yang wajar. Apalagi banyak masyarakat yang menikahkan anak-anaknya di usia itu ataupun satu tahun diatas itu karena hamil diluar nikah. Menikahkan VJ tidak hanya sekedar menghindari gunjingan masyarakat, akan tetapi juga memberi identitas yang jelas kepada anak VJ setelah lahir. Sebagaimana yang diungkapkan oleh informan berikut ini:

... "Saya menikahkan VJ bukan karena hamil diluar nikah akibat dari pergaulan bebas, melainkan untuk pemberian identitas anak yang dikandung VJ, akan tetapi untuk menghindari beban sosial dari masyarakat. Jika anak yang dikandung VJ lahir tanpa seorang ayah, maka anak itu dikatakan anak haram di dalam masyarakat. Kata anak haram itu akan terus melekat pada diri anak tersebut" ... (Wawancara, 14 November 2019)

Keterangan lanjutan IN itu begitu sederhana bahwa dia menikahkan anaknya dengan harapan anak yang dikandung oleh VJ lahir nanti tidak dikatakan sebagai anak haram karena tidak memiliki ayah yang jelas. Bagi IN kata anak haram itu sangat menyakitkan dan sangat berdampak pada kondisi anak setelah besar nanti. Di dalam masyarakat kata labelling itu akan selalu di sematkan kepada pelaku yang dianggap menaati peraturan agama dan adat istiadat. 
Jurnal Pendidikan Geografi:

Kajian, Teori, dan Praktik dalam Bidang Pendidikan dan Ilmu Geografi

Volume 25, Nomor 2, Jun 2020, Hal 128-144

Sama halnya dengan subyek yang lain, latarbelakang dilakukannya pernikahan usia dini oleh BA terhadap anaknya yang bernama VIJ juga karena hamil diluar nikah dengan kata lain Married By Accident (MBA) karena pergaulan yang bebas. BA merupakan orang tua dari VIJ, dia menikahkan VIJ di usia 14 tahun. Saat itu VIJ menyampaikan kepada BA bahwa dia ingin menikah karena sudah hamil. Berikut ini ungkapan yang disampaikan oleh informan kepada peneliti:

\begin{abstract}
... "Saat itu saya lagi duduk sendirian diatas kursi diruang tamu sedang menonton $\mathrm{TV}$, kemudian VIJ datang menghampiri saya. VIJ duduk didekat saya, VIJ terlihat gugup hendak ingin berbicara dengan saya. Saya bertanya kepada VIJ, apa yang ingin kamu bicarakan kepada saya? VIJ menjawab dengan gugupnya seraya berkata, saya mau menikah bapak karena saya sudah hamil 4 bulan. Saat itu saya kaget dan langsung menanyakan siapa yang menghamilinya. Setelah saya tahu siapa yang menghamilinya, saya mendatangi keluarga laki-laki itu dan minta pertanggung jawaban atas perbuatan anaknya. Singkat cerita, saya menikahkan VIJ. Saya menikahkan VIJ untuk menghindari malu keluarga saya dari masyarakat" ... (Wawancara, 14 November 2019)
\end{abstract}

Berdasarkan keterangan BA tersebut, VIJ dinikahkan di usia yang masih muda belia karena hamil diluar nikah akibat dari pergaulan bebas. Melihat perut VIJ yang semakin hari semakin membesar tidak mungkin VIJ harus menjalani sendirian dan harus ada yang mendampinginya. Motif sebab (because motives) BA menikahkan anaknya di usia dini yaitu karena hamil diluar nikah sedangkan Tujuan (in order to motives) yaitu untuk menghindari beban sosail dari masyarakat.

BA memaknai pernikahan usia dini yang dilakukannya terhadap anak pertamanya yang bernama VIJ itu karena menghindar rasa malu keluarga dari masyarakat. Malu itu bagi BA merupakan identitas yang nyata bagi pemegang teguh adat istiadat dan agama. Jika sesorang tidak memiliki rasa malu, dia aka merasa bodoh atas semua kesalahan yang dilakukannya didalam masyarakat. Bagi BA tujuan (in order motives) menikahkan anaknya yaitu untuk mengindari gunjingan msayarkat terhadap keluarganya. Gunjingan masyarakat itu akan membuat kenyaman dan keamanan keluarganya menjadi tergangu.

Selain dari RD, IN, dan BA, AR juga menikahkan anaknya di usia dini dengan alasan hamil diluar nikah karena pergaulan anaknya yang bebas. Anak AR yang dinikahkan di usia dini bernama MA. MA merupakan anak kedua dari lima bersaudara yang menikah di usia 15 tahun. AR terpaksa menikahkan anaknya yang masih muda belia karena hamil duluan akibat dari pergaulan bebas. Hal ini dapat dilihat dari ungkapan informan berikut ini:

\footnotetext{
... "Anak saya yang kedua bernama MA, dia saya nikahkan saat usia 15 tahun. Saya tidak menjodohkannya, tidak pula memaksakannya menikah di usia tersebut, melainkan hamil diluar nikah karena pergaulannya yang bebas. Hamil diluar nikah tidak bisa dibiarkan begitu saja tanpa melakukan pernikahan, mau tidak mau harus segera dinikahkan tanpa ada penundaan" ... (Wawancara, tanggal 15 November 2019)
}

Berdasarkan ungkapan AR tersebut, dapat dipahami bahwa AR menikahkan anaknya dengan alasan hamil diluar nikah karena pergaulan bebas. AR tidak memiliki alasan yang kuat untuk tidak menikahkan anaknya. anak AR yang menikah karena hamil diluar nikah bernama MA. MA menikah di usia 15 tahun dan suaminya berusia 22 tahun. MA menceritakan bahwa sanya dia berkenalan dengan suaminya saat sedang duduk di depan rumahnya di sore hari. Perkenalan dihari ketiganya MA mulai suka dan membuat 
Jurnal Pendidikan Geografi:

Kajian, Teori, dan Praktik dalam Bidang Pendidikan dan Ilmu Geografi

Volume 25, Nomor 2, Jun 2020, Hal 128-144

hubungan berupa pacara. Pacaran mereka hanya berlangsung selama 6 hari. Hari ke 6 MA melakukan hubungan selayaknya suami istri dan akhirnya hamil.

Melihat perutnya semakin membesar, MA menyampaikan kepada AT dan AR bahwa dia hamil dan saat itu kehamilannya memasuki usia 4 bulan. AT tidak memiliki alasan untuk tidak menikah dengan MA, karena dia harus bertanggung jawab atas perbuatannya dan AR pun tidak memiliki alasan yang sangat kuat untuk tidak menikahkan MA dengan AT. Ungkapan tersebut terlihat dari apa yang diungkapkan oleh informan berikut ini:

\begin{abstract}
... "Saya sangat bahagia karena bisa menikahkan MA dengan AT. Melalui pernikahan itu, saya telah mampu menghindari gunjingan keluarga saya dari masyarakat. Selain dari itu, saya juga telah memberikan identitas yang jelas pada anak yang sedang dikandung MA setelah lahir nanti anak tersebut memiliki ayah. Ayah dari anak itulah yang akan menutup aib dari kata anak haram" ... (Wawancara, tanggal 15 November 2019)
\end{abstract}

Ungkapan AR tersebut menjelaskan bahwa motif tujuan (in order to motives) dari pernikahan usia dini yang dilakukan olehnya untuk menghindari gunjingan dari masyarakat. Gunjingan tersebut akan membuat keberadaannya dan keluarga dalam masyarakat tidak nyaman. AR bahagia karena telah menikahkan MA dengan AT. Makna yang terkandung dalam pernikahan yang dilakukan oleh AR antara MA dan AT yaitu memberikan identitas yang jelas pada seorang anak yang sedang dikandung MA. Ketika anak itu lahir nanti, anak itu memiliki ayah yang jelas.

Makna tindakan pernikahan usia dini yang dilakukan oleh AR terhadap anaknya MA yaitu untuk menghindari malu keluarga dari masyarakat sekitar. Rasa malu bagi AR adalah sesuatu hal yang harus dipegang teguh dalam melakukan setiap tindakan, agar disetiap tindakan yang dilakukan dikaji terlebih dahulu dampak dari tindakan yang akan dilakukan. Sekalipun anaknya bernama MA melakukan tindakan yang membuat keluarganya malu, bagi AR malu itu tetap harus dihindarkan.

Alasan yang sama dengan subyek lainnya, latarbelakang pernikahan usia dini yang dilakukan oleh KU terhadap anak pertamanya yang bernama DPDM. KU menikahkan anaknya di usia dini karena hamil diluar nikah akibat pergaulan bebas yang dilakukan oleh anaknya. Hal ini diungkapkan melalui penuturannya:

\footnotetext{
... "Saya menikahkan anak saya DPDM di usia 16 tahun. Dia saya nikahkan karena hamil diluar nikah akibat pergaulan bebas. Hamil diluar nikah ini jika tidak dinikahkan, membuat keluarga akan menjadi bahan gunjingan masyarakat. Jika sudah menjadi bahan gunjingan masyarakat, keluarga akan menjadi malu. Mau tidak mau harus dinikahkan walaupun disaat itu DPDM masih duduk dibangku sekolah" ... (Wawancara, tanggal 15 November 2019)
}

Ungkapan KU tersebut menjelaskan bahwa makna menikahkan DPDM di usia dini adalah upaya untuk menhindari malu dari masyarakat. KU tidak ada sama sekali menyesal menikahkan anaknya di usia 15 tahun. Seharusnya di usia itu anaknya masih bermain-main dengan anak-anak lainnya dan sekolah. Demi menghindari malu keluarga dari masyarakat, KU harus menikahkan DPDM dengan CHD. Padahal saat menikahkan anaknya DPDM itu, KU baru saja ditinggal pergi selama-lamanya. Bagi KU diibaratkan seperti pepatah "Sudah jatuh tertimpa tangga" artinya sudah ditinggal istri, anak melakukan perbuatan yang dibenci oleh agama dan adat yaitu hamil diluar nikah.

Motif sebab (because motives) KU menikahkan anaknya DPDM di usia dini karena pergaulan bebas membuat DPDM hamil diluar nikah. Hamil diluar nikah ini tidak 
Jurnal Pendidikan Geografi:

Kajian, Teori, dan Praktik dalam Bidang Pendidikan dan Ilmu Geografi

Volume 25, Nomor 2, Jun 2020, Hal 128-144

memiliki alasan yang kuat untuk tidak dilakukan pernikahan sekalipun DPDM masih duduk dibangku sekolah. Motif tujuan (in order to motives) KU menikahkan DPDM di usia dini adalah untuk menghindari gunjingan masyarakat. Pernikahan usia dini sudah biasa dilakukan di desanya apalagi pernikahan yang dilakukan karena pergaulan bebas yang berdampak hamil diluar nikah. Jika DPDM tidak dinikahkan, maka seumur hidup akan menjadi bahan gunjingan tetangga dan masyarakat sampai anak yang dikandung DPDM lahir pun akan dijadikan bahan pembicaraan.

Studi pemaknaan dari teori Alfred Schutz mengatakan bahwa studi makna tidak akan pernah terlepas dari motif sebab (because motives) dan motif tujuan (in order to motives) untuk memahami tentang pernikahan usia dini. Pemaknaan pernikahan usia dini yang disebabkan oleh pergaulan bebas mengakibatkan hamil diluar nikah tidak terlepas dari motif sebab (because motives) yaitu pergaulan bebas dan motif tujuan (in order to motives) yaitu menghindari gunjingan masyarakat dan pemaknaanya yaitu menghindari malu. Subyek yang memaknakan pernikahan dini hasil dari pergaulan bebas yaitu: RD anaknya bernama NS, IN anaknya bernama VJ, BA anaknya bernama VIJ, AR anaknya bernama MA, dan KU anaknya bernama DPDM.

\section{Pernikahan Usia Dini Sebagai Upaya Membantu Perekonomian}

Setiap orang tua mengetahui bahwa pendidikan sangat penting bagi kecerdasan anak-anak mereka, tetapi tidak semua orang tua memiliki biaya yang cukup untuk menyekolahkan anak-anak mereka ke jenjang yang lebih tinggi. Bagi orang tua yang memiliki anak perempuan usia sekolah, namun tidak lagi melanjutkan sekolah karena masalah ekonomi, maka mereka sangat berpotensi untuk dinikahkan apalagi mereka yang sudah memasuki masa remaja awal dan akhir.

Masyarakat Nagari Tapan merupakan masyarakat yang mayoritas memiliki perekonomian yang sangat tinggi dan produktif, sehingga kehidupannya terjamin. Perekonomian yang tinggi tidak menutup kemungkinan berdampak terhadap pendidikan, namun masih ada masyarakat yang perekonomiannya sangat rendah sehingga berdampak pada pendidikan. Kondisi perekonomian yang rendah inilah membuat beberapa anak putus sekolah. Salah satu subyek yang menikahkan anaknya karena perekonomian rendah yaitu SI.

SI memikahkan dua anaknya di usia dini karena putus sekolah. Putus sekolah kedua anak SI erat kaitannya dengan masalah perekonomian keluarga. SI menikahkan anak pertamanya yang bernama SP di usia dini saat usia 16 tahun sedangkan anak keduanya bernama MK saat usia 13 tahun. SI selama ini bekerja sebagai petani pemetik sayur paku di hutan, sedangkan KA bekerja sebagai penggarap sawah dan kebun orang lain. Hasil dari penjulan sayur paku yang dipetik oleh SI dari hutan sebesar Rp 30.000/ hari dan itu pun jika sayur pakunya tumbuh. Harga satu ikat sayur paku yaitu Rp 1000.

Upah kerja KA sendiri sebesar Rp 100.000/hari, itu pun jika KA mendapatkan kerja dari para pemilik sawah dan kebun. Selain pendapatan dari hasil kerja SI dan KA, keluarga SI menjual pancang. Harga satu buah pancang sebesar Rp 5000, pancang terjual dalam satu hari yaitu 25-30 buah. Jika harga pancang sebesar Rp 5000/buah, maka dalam satu hari KA dan SI dapat mengumpul uang sebesar Rp 150.000, akan tetapi pancang yang dijual KA dan SI tidak terjual setiap harinya. Di lihat semua pendapatan dari SI dan KA serta hasil penjualan pancang awalnya bisa menutupi kebutuhan anaknya sekolah. Namun pada saat SI mengalami sakit Jatung membuat mereka membutuhkan banyak uang untuk berobat dan kontrol setiap harinya kerumah sakit.

Melihat kondisi keuangan yang sangat tidak stabil antara pendapatan dan pengeluaran, akhirnya SP dan MK memutuskan dirinya berhenti sekolah dan membantu 
Jurnal Pendidikan Geografi:

Kajian, Teori, dan Praktik dalam Bidang Pendidikan dan Ilmu Geografi

Volume 25, Nomor 2, Jun 2020, Hal 128-144

bekerja untuk memenuhi kebutuhan sehari-hari keluarga KA. Setahun setelah berhenti sekolah, SP dan MK memutuskan untuk menikah dan calonnya pun sudah ada. Sebagaimana yang diungkapkan oleh informan sebagai berikut:

... "SP dan MK saya nikahkan di usia dini saat itu SP berusia 16 tahun dan MK berusia 13 tahun. Mereka berdua saya nikahkan di usia dini karena masalah ekonomi rendah. Apalagi mereka sudah tidak sekolah. Awalnya mereka berdua sekolah, karena saya sakit jantung membuat perekonomian keluarga kami tidak setabil, membuat SP dan MK harus putus sekolah dan menikah setelah satu tahun tidak sekolah. Tujuan saya menikahkan mereka agar dapat membantu perekonomian keluarga" ... (Wawancara, tanggal 15 November 2019)

Ungkapan SI tersebut menjelaskan bahwa pernikahan usia dini yang dilakukannya terhadap dua anaknya SP dan MK yaitu karena masalah ekonomi sehingga mereka putus sekolah dan membuat mereka dinikahkan di usia dini. Melihat SP dan MK tidak sekolah lagi, difikiran SI hanya ingin segera menikahkan anak-anaknya agar setelah menikah nanti mereka dapat membantu perekonomian keluarganya. Awal setelah menikah, SP dan MK tinggal satu rumah dengan oarangtuanya. Melihat suami SP dan MK memiliki kerja tetap yaitu buruh tani, kedua-dua anaknya itu membangun rumah dan tinggal disana. Walaupun kedua anaknya tinggal dirumahnya masing-masing, kedua anaknya tetap membantu perekonomian SI dan KA.

Sama halnya dengan SI, IJ menikahkan anaknya di usia dini karena masalah ekonomi. Hal ini dapat dilihat dari apa yang diungkapkan oleh informan berikut ini:

\footnotetext{
... "Saya menikahkan anak bungsu di usia dini karena masalah ekonomi. Apalagi sudah tidak sekolah. Anak bungsu saya bernama LOP menikah saat usia 15 tahun. Pernikahan itu terjadi tidak ada alasan lain selain masalah ekonomi keluarga dan saat itupun ada seorang laki-laki datang melamar LOP. Kami tidak bisa menolak lamaran laki-laki itu, melihat laki-laki itu juga termasuk orang yang pekerja keras dan dapat membantu perekonomian keluarga nantinya" ... (Wawancara, tanggal 16 November 2019)
}

Dilihat dari ungkapat IJ tersebut, dapat disimpulkan bahwa IJ menikahkan anaknya di usia dini karena masalah ekonomi. IJ menikahkan anak bungsunya yang bernama LOP saat usia 15 tahun dan usia 15 tahun itu masih dikatakan sangat muda belia. IJ tidak punya alasan lain untuk tidak menikahkan anaknya selain karena masalah ekonomi. IJ menjelaskan kepada peneliti bahwa sama sekali dia tidak menjodohkan anaknya melainkan ada laki-laki yang datang melamar anaknya kerumah.

IJ tidak bisa menolak lamaran laki-laki tersebut karena laki-laki tersebut merupakan anak pekerja keras dan perkerjaannya jelas. Melihat LOP juga ingin menikah dan jodohnya pun ada, IJ menikahkan LOP dengan tujuan agar dapat mengurangi beban ekonomi keluarga. Setelah LOP menikah, LOP tinggal bersama IJ dalan satu rumah. LOP tinggal bersama IJ dengan alsan dapat membantu mengurangi beban ekonomi ibunya. LOP merasa kasihan melihat IJ sendirian memikirkan masalah ekonomi semenjak AR suaminya meninggal dunia.

AR memaknai pernikahan dini yang dilakukannya terhadap anak bungsunya yaitu LOP yaitu membantu perekonomian keluarga. Menikahkan anaknya dengan orang yang memiliki pekerjaan tetap dan penghasilan yang jelas akan memberikan kesejahteraan dalam keluarga. Semua kebutuhan primer akan terpenuhi setiap harinya dan sebagian pendapatan akan dapat disimpan sebagai simpanan ketika butuh nantinya. Walaupun memiliki menantu dengan penghasilan yang besar, IJ mengajarkan anaknya bagaimana menjadi seseorang yang mampu mengatur keuangan dalam keluarga. 
Jurnal Pendidikan Geografi:

Kajian, Teori, dan Praktik dalam Bidang Pendidikan dan Ilmu Geografi

Volume 25, Nomor 2, Jun 2020, Hal 128-144

Sama seperti subyek lainnya, AI menikahkan anak pertamanya yang bernama NH di usia dini dengan alasan masalah ekonomi rendah. AI menikahkan NH saat usia 15 tahun, tepatnya dua tahun yang lalu. Hal ini dapat dilihat dari ungkapan oleh informan berikut ini:

\begin{abstract}
... "Anak saya saat itu menikah usia 15 tahun. Dia saya nikahkan karena ekonomi rendah. Apalagi saat itu dia sudah tidak sekolah lagi. Saat itu kebetulan pacar anak saya datang kerumah dengan tujuan untuk melamar. Saya tidak menolak lamaran itu karena dengan menikahkan anak saya dapat membantu perekonomian keluarga"... (Wawancara, tanggal 16 November 2019)
\end{abstract}

Berdasarkan ungkapan AI tersebut, AI memaknai pernikahan usia dini yaitu masalah ekonomi. Anak yang dinikahkan oleh AI saat usia dini bernama NH. NH merupakan anak pertamanya. NH menikah saat usia 15 tahun, tepatnya dua tahun yang lalu. Tujuan AI menikahkan $\mathrm{NH}$ yaitu agar melalui pernikahan $\mathrm{NH}$ itu dapat memperbaiki perekonomian keluarganya melihat pekerjaan calon suami NH saat itu kuli bangunan. Di Nagari Tapan menganggap bahwa kuli bangunan adalah pekerjaan yang menjajikan.

Sebelum menikah, suami NH bekerja sebagai kuli bangunan dan setelah menikah pun bekerja sebagai kuli bangunan. Bekerja sebagai kuli bangunan merupakan perkejaan yang menjanjikan untuk kesejah teraan keluarga. Walaupun sudah menikah, NH dan suaminya tinggal bersama ibunya. Tinggal bersama orangtuanya sama halnya membantu perekonomian kedua orangtuanya.

Studi pemaknaan dari teori Alfred Schutz mengatakan bahwa studi makna tidak akan pernah terlepas dari motif sebab (because motives) dan motif tujuan (in order to motives) untuk memahami tentang pernikahan usia dini. Pemaknaan pernikahan usia dini yang disebabkan oleh ekonomi tidak terlepas dari motif sebab (because motives) yaitu ekonomi rendah dan motif tujuan (in order to motives) yaitu mengurangi beban ekonomi keluarga dan pemaknaanya yaitu membantu perekonomian. Subyek yang memaknakan pernikahan dini membantu perekonomian yaitu: SI anaknya bernama SP dan MK, IJ anaknya bernama LOP, dan AS anaknya bernama NH.

\title{
Pernikahan Usia Dini Sebagai Upaya Penyelamatan
}

Pola pernikahan hasil dari tacobak (gerebek) di Nagari Tapan Kecamatan Basa Ampek Balai Tapan Kabupaten Pesisir Selatan Provinsi Sumatera Barat ini bukan sesuatu hal yang tabu lagi. Pernikahan hasil dari tacobak (gerebek) ini bertujuan untuk upaya penyelamatan pihak laki-laki dan perempuan. Pernikahan hasil tacobak (gerebek) ini tidak melihat tingkatan umur, anak siapa, dari kalangan mana, dan status pendidikan. Siapa saja yang terkena gerebekan mereka wajib dinikahkan. Jika digerebeknya pada pagi atau siang hari, maka dinikahkan saat itu juga. Jika digerebeknya di malam hari, maka akan dinikahkan besok paginya. Hal itu berlaku sampai kapan pun, dimana pun, dan siapa pun.

Pernikahan usia dini hasil dari tacobak (gerebek) ini akan terus dilakukan apabila ada remaja maupun orang dewasa yang digerebek. Makna yang terkandungan dari pernikahan hasil tacobak (gerebek) ini sebagai upaya penyelamatan pihak laki-laki dan perempuanl. Subyek penelitian yang memaknai pernikahan usia dini upaya penyelamatan adalah AR, sebagaimana yang diungkapkannya pada peneliti sebagai berikut:

... "Anak saya yang pertama bernama ES, dia saya nikahkan di usia 15 tahun. Saya tidak pernah menjodohkannya dan tidak pula memaksakannya menikah. Dia saya nikahkan karena hasil tacobak (gerebek) di malam hari. 
Jurnal Pendidikan Geografi:

Kajian, Teori, dan Praktik dalam Bidang Pendidikan dan Ilmu Geografi

Volume 25, Nomor 2, Jun 2020, Hal 128-144

Jika tidak saya nikahkan takutnya nanti dia hamil, karena saya tidak tahu apa yang dilakukannya saat berdua-duaan dengan pacarnya" ... (Wawancara, tanggal 15 November 2019)

Berdasarkan ungkapan AR tersebut dapat dipahami bahwa beliau menikahkan anaknya di usia dini karena untuk menyelamatkan antara yang laki-laki dengan anaknya. Jika anaknya tidak dinikahkan dan ternyata anaknya hamil maka anaknya akan dikuncilkan dari masyarakat dan tidak dinikahkan. AR menikahkan ES di usia 15 tahun. ES menceritakan bahwa sebelum menikah dengan suuaminya, mereka pacaran dan sering ketemuan terutama pada malam minggu. Pertemuan yang dilakukan setiap malam minggunya membuat saya lupa akan waktu batas penerimaan tamu dan saat itulah tacobak (gerebek) terjadi.

Melihat kejadian tacobak (gerebek) itu telah terjadi, AR harus menikahkan anaknya karena harus mengikuti aturan adat yang berlaku didaerahnya. Jika tacobak (gerebek) di pagi dan siang hari, maka dinikahkan hari itu juga. Jika tacobak (gerebek) terjadi pada malam hari, maka dinikahkan pagi hari. Anaknya sendiri digerebek pada malam hari, maka dari itu dinikahkan pagi hari. Harapan AR menikahkan anaknya agar peraturan adat istiadat itu ditegakkan dengan adil. Hal ini dapat dilihat dari ungkapan informan berikut ini:

\begin{abstract}
... "Saya sangat bahagia sudah menikahkan anak saya bernama ES. Saya menikahkannya sama saja saya telah mentaati peraturan adat istiadat yang berlaku didaerah kami. Peraturan adat istiadat didaerah kami bertujuan agar menjalani adab-adab bertamu. Jika tidak dinikahkan anak saya akan mendapatkan sanksi berupa dikeluarkan dari daerahnya" ... (Wawancara, tanggal 15 November 2019)
\end{abstract}

Ungkapan AR tersebut menjelaskan bahwa motif tujuan (in order to motives) dari pernikahan usia dini yang dilakukannya pada anak pertamanya untuk menjalani peraturan adat istiadat daerahnya. Sebagai warga yang baik dan taat akan peraturan adat istiadat, AR harus mengikuti setiap proses dari adat istiadat dan menerima setiap hukuman dari adat istiadat atas perbuatan anaknya. AR bahagia telah mampu menjadi warga yang taat akan pada peraturan adat istiadat.

Sejalan dengan pandangan AR, MR menikahkan anaknya di usia dini karena digerebek. Hal ini diungkapkannya melalui penuturannya:

\footnotetext{
... "Saya menikahkan anak saya di usia 15 tahun. Dia saya nikahkan karena digerebek oleh para pemuda saat berdua-duaan di dalam rumah tanpa didampingi oleh kami. Saya tidak bisa menolak untuk anak saya tidak dinikahkan, saya ingin menyelamatkan pasangan anak saya dan anak saya. Soalnya saya tidak tahu apa yang terjadi pada anak saya saat berdua-duaan di dalam rumah" ... (Wawancara, tanggal 15 November 2019)
}

Berdasarkan ungkapan MR tersebut diketahui bahwa MR memaknai pernikahan usia dini adalah upaya untuk menyelamatkan pasangan anakknya dan anaknya sendiri. Motif sebab (because motives) MR menikahkan anaknya di usia dini karena tacobak (gerebek) yang terjadi dimalam hari. Anak pertama yang dinikahkan oleh MR di usia dini bernama MS. MS dinikahkan oleh MR di usia 15 tahun dan masih sekolah. MR tidak bisa menolak terjadinya pernikahan itu, sekalipun anaknya masih duduk di bangku sekolah. Konsekwensi dari orang yang digerebek yaitu wajib dinikahkan.

Motif tujuan (in order to motives) dari pernikahan usia dini yang dilakukan oleh MR terhadap anak pertamanya yaitu karena menjalani peraturan adat istiadat yang 
Jurnal Pendidikan Geografi:

Kajian, Teori, dan Praktik dalam Bidang Pendidikan dan Ilmu Geografi

Volume 25, Nomor 2, Jun 2020, Hal 128-144

berlaku didaerahnya. Pernikahan usia dini hasil dari tacobak (gerebek) sudah sering terjadi didaerahnya dan dianggap menjadi sesuatu hal yang sudah biasa dan tidak tabu lagi. Jika MR tidak menikahkan anaknya, berarti dia telah melakukan pelanggaran peraturan adat istiadat yang berlaku di masyarakat.

Saat ini MS berusia 19 tahun. Di usia yang masih dikatakan muda dia sudah menjadi seorang janda beranak satu. MS di ceraikan oleh suaminya yang bernama CNF karena ketidak cocokan lagi antara mereka berdua. MS beserta anaknya saat ini tinggal bersama kedua orangtuanya dan menjadi tanggung jawab kedua orantuanya. CNF suami MS sama sekali sudah tidak memberi uang lagi untuk biaya anaknya.

Harapan MR ternyata tidak sesuai dengan kenyataannya, dia harus menghidupi anak dan cucunya yang masih kecil. Hal ini sesuai apa yang diungkapkan oleh informan berikut ini:

\footnotetext{
... "Saya sangat bahagia menikahkan MS dengan CNF. Saya melihat CNF adalah anak yang bertanggung jawab dan berbakti kepada kedua orang tua. Selain itu dilihat dari latarbelakng keluarga CNF pun dari keluarga yang sangat baik. Namun kenyataannya semua yang saya lihat hanyalah balutan kebaikan dengan kenyataannya begitu pahit" ... (Wawancara, tanggal 15 November 2019)
}

Ungkapan MR tersebut menjelaskan secara tegas bahwa dia menikahkan anaknya dengan CNF karena dia anak yang baik dan bertanggung jawab. MR yakin menikahkan MS dengan CNF akan memberikan kebahgiaan yang hakiki bagi MS, namun itu semua bertolak belakang dengan sebenarnya. MS harus menjadi seorang jandan dan harus menghidupi anaknya semata wayang dengan sendirinya tanpa kehadiran CNF disampinya.

Sama halnya dengan subyek sebelumnya yang menjadi latarbelakang YA menikahkan anaknya di usia dini yaitu VOS upaya menyelamatkan VOS dengan pasangannya. YA merupakan orang tua dari VOS, YA menikahkan VOS saat usia 16 tahun dan masih duduk di bangku sekolah. Saya sebenarnya bisa menolak pernikahan itu tapi, bukan karena untuk menyelamatkan pasangan anak saya dan anak saya sendiri jika tidak dinikahkan ternyata hamil, anak saya akan dikeluarkan dari kampung dan tidak akan dinikankan lagi. Hal ini sesuai dengan apa yang diungkapkan oleh informan berikut ini:

\footnotetext{
... "Saya menikahkan VOS di usia dini karena tacobak (gerebek). Saat itu pernikahan dilakukan ketika VOS berusia 16 tahun. Saya menikahkan VOS sebagai upaya untuk menyelamatkan pasangan anak saya dan anak saya sendiri serta mengikuti peraturan adat istiadat yang berlaku di daerah saya. Adat istiadat saya mengatakan bahwa anak yang terkena gerebekan harus dinikahkan sebagai antisipasi hamil" ... (Wawancara, tanggal 15 November 2019)
}

Sesuai dengan apa yang diungkapkan oleh YA tersebut, YA memaknai pernikahan usia dini yang dilakukannya yaitu sebagai upaya untuk menyelamatkan pasangan anaknya dan anaknya agar tidak dibuang dari kampung. VOS merupakan anak pertama YA yang dinikahkan di usia 16 tahun dan disaat itu VOS masih duduk di bangku sekolah. Menikahkan anak karena hasil tacobak (gerebek) merupakan bentuk pernikahan yang tidak bisa ditolak dalam adat istiadat.

Motif sebab (because motives) YA melakukan pernikahan usia dini pada anaknya VOS karena tacobak (gerebek) saat berdua-duaannya di dalam rumah tanpa didampingi 
Jurnal Pendidikan Geografi:

Kajian, Teori, dan Praktik dalam Bidang Pendidikan dan Ilmu Geografi

Volume 25, Nomor 2, Jun 2020, Hal 128-144

oleh orangtuanya. Tacobak (gerebek) ini tidak dilakukan secara cepat akan tetapi dilihat dari berapa kali mereka melakukan berdua-duaany di dalam rumah tanpa didampingi orang tua dan jam berapa akhir dari pertemuan mereka. Jika sudah sering, maka tacobak (gerebek) akan dilakukan.

Motif tujuan (in order to motives) YA menikahkan VOS di usia dini yaitu menjalani pertauran adat istiadat yang berlaku di masyarakat. Adat istiadat ini bersifat universal di dalam masyarakat karena tidak memandang status seseorang, pendidikan, jabatan, dan kedudukan. Setiap yang melanggar peraturan adat istiadat akan mendapatkan sanksi sesuai dengan apa yang dilanggar. Tujuan lain dari adanya peraturan adat istiadat ini yaitu untuk menjadi kehormatan perempuan dan laki-laki di dalam masyarakat.

Selain dari AR, MR, dan YA, LS juga menikahkan anaknya di usia dini akibat dari tacobak (gerebek). Tacobak (gerebek) ini tidak melihat usia orangnya. Jika terkena tacobak (gerebek) maka wajib menikah. Hal ini sesuai dengan ungkapan informan berikut ini:

\footnotetext{
... "Anak saya menikahkan di usia 16 tahun. Saya menikahkannya di usia dini karena tacobak (gerebek). Disaat itu anak saya berdua-duaan di dalam rumah tanpa didampingi oleh saya dan suami saya. Mereka berdua-duaan lewat dari pukul 22.00 WIB. Dilihat dari peraturan bertamu itu telah melanggar peraturan bertamu. Saya tidak memiliki alasan untuk menolak pernikahan itu" ... (Wawancara, tanggal 16 November 2019)
}

Ungkapan LS tersebut dapat diketahui bahwa beliau menikahkan anaknya karena hasil tacobak (gerebek). Tacobak (gerebek) dilakukan saat saya tidak ada dirumah. Anak LS yang dinikahkan di usia dini bernaa LPA yang dinikahkan saat usia 16 tahun dan masih duduk di bangku sekolah. LS tidak memiliki alasan yang sangat kuat untuk tidak menikahkan anaknya melihat anaknya masih duduk di bangku sekolah. Jika saya tidak menikahkan LPA, saya takut LPA hamil karena saya tidak tahu apa yang mereka lakukan saat berdua-duaan di dalam rumah tanpa didampingi oleh saya. Jika hamil dan tidak dinikahkan, maka LPA dan pasangannya akan dikeluarkan dari kampung. Sebagaimana yang diungkapkan oleh informan sebagai berikut:

\begin{abstract}
... "Saya menikahkan LPA sebagai bentuk antisipasi LPA hamil karena saya tidak tahu apa yang dilakukan oleh LPA dengan RE saat berdua-duaan di dalam rumah. Sebagai bentuk penyelamatan antara pasangan anak saya dan anak saya agar tidak dikeluarkan dari kampung karena tidak mau menikah, maka saya menikahkan LPA dengan RE sekalipun mereka samasama masih sekolah"... (Wawancara, tanggal 16 November 2019)
\end{abstract}

Ungkapan LS tersebut menjelaskan bahwa LS memaknai pernikahan usia dini yang dilakukannya terhadap anak keduanya yaitu upaya untuk menyelamatkan pasangan anaknya dan anaknya sendiri agar tidak dikeluarkan dari kampung. Anak LS akan dikeluarkan dari kampung jika tidak dinikahkan dan ternyata anaknya itu hamil. LS tidak tahu apa yang dilakukan oleh LPA dan RE saat berdua-duaan di dalam rumah. Jika tidak dinikahkan dan teryata hamil, maka keluarga LS akan menanggung semua akibat dari keputusannya dan tidak akan bisa meminta pertanggung jawaban dari pihak laki-laki dan akan dikeluarkan dari kampung.

Motif tujuan (in order to motives) pernikahan dini yang dilakukan oleh LS terhadap anaknya keduanya yang bernama LPA yaitu untuk menjalani peraturan adat istiadat yang berlaku di masyarakat. Jika LS tidak menjalani peraturan adat istiadat yang 
Jurnal Pendidikan Geografi:

Kajian, Teori, dan Praktik dalam Bidang Pendidikan dan Ilmu Geografi

Volume 25, Nomor 2, Jun 2020, Hal 128-144

berlaku di masyarakat, maka anak LS akan dikeluarkan dari masyarakat tersebut. Ketika anak LS sudah keluar dari masyarakat, maka anak LS tidak bisa dinikahkan di dalam kampung itu dan harus di luar kampung itu sendiri. Setelah menikahpun harus tinggal di luar kampung.

Alasan yang sama dengan subyek lainnya, MS menikahkan anaknya di usia dini yaitu karena hasil tacobak (gerebek). Informan mengungkapkannya melalui penuturannya berikut ini:

\footnotetext{
... "Anak saya menikah di usia 14 tahun. Dia saya nikahkan karena tacobak (gerebek) yang dilakukan oleh para pumuda yang berada disekitar rumah saya. Saya tidak bisa menolak pernikahan itu selain karena tacobak (gerebek), anak saya juga sudah tidak lagi sekolah, akhirnya saya menikahkannya" ... (Wawancara, tanggal 16 November 2019)
}

Berdasarkan ungkapan tersebut, dapat diketahui alasan MS menikahkan anaknya di usia dini yaitu karena hasil tacobak (gerebek). Pernikahan usia dini yang dilakukan oleh MS terhadap anak bungsunya yang bernama PO. PO ini merupakan anak didik peneliti disaat dikampung dulu berprofesi sebagai pengajar TPQ dan TPSQ. Selama menjadi murid peneliti waktu di TPQ dan TPSQ, PO ini anak yang kalem dan tidak memiliki tingkah laku yang aneh. Tidak tahu kenapa setelah besar dia memiliki sifat yang tidak pernah diajarkan saat dia di TPQ dan TPSQ dulu. MS menikahkan anaknya disaat itu berusia 14 tahun. Selain dari alasan hasil tacobak (gerebek), MS menikahkan anaknya karena sudah tidak sekolah lagi.

MS memiliki motif tujuan (in order to motives) dilakukannya pernikahan usia dini kepada anak bungsunya yaitu untuk menjalani peraturan adat istiadat yang berlaku di masyarakat. Adat istiadat ini memiliki tujuan yaitu untuk menjaga kehormatan antara laki-laki dan perempuan. Bagi adat istiadat laki-laki dan perempuan merupakan bagian dari adat itu sendiri. Adat itu akan berjalan dengan baik jika pelaku dari adat istiadat itu baik. Menikahkan anak hasil dari tacobak (gerebek) akan menyelamatkan kedua pasangan. Sebagaimana yang diungkapkan oleh informan berikut ini:

\footnotetext{
... “Anak saya menikah karena sebagai upaya untuk menyelamatkan anak saya dan pasangannya. Saya takut anak saya hamil. Saya tidak tahu apa yang dilakukannya saat berdua-duaan di dalam rumah. Apalagi mereka berdua-duaan disaat kami tidak ada dirumah. jika anak saya hamil dan tidak saya nikahkan, maka anak saya akan dikeluarkan dari kampung" ... (Wawancara, tanggal 16 November 2019)
}

Berdasarkan ungkapan tersebut, MS memaknai pernikahan dini yang dilakukannya pada anak bungsunya yaitu sebagai upaya penyelamatan anaknya dengan pasangannya. MS tidak mengetahui apa yang dilakukan PO disaat berdua-duaan dengan RS di dalam rumah tanpa didampingi oleh saya. Saya takut hamil karena disaat berduaduaan di dalam rumah tanpa didampingi yang ketiganya adalah syaitan. Saya takut saat itu mereka khilaf dan melakukan hal-hal yang dilarang agama.

Studi pemaknaan dari teori Alfred Schutz mengatakan bahwa studi makna tidak akan pernah terlepas dari motif sebab (because motives) dan motif tujuan (in order to motives) untuk memahami tentang pernikahan usia dini. Pemaknaan pernikahan usia dini yang disebabkan oleh tacobak (gerebek) tidak terlepas dari motif sebab (because motives) yaitu tacobak (gerebek) dan motif tujuan (in order to motives) yaitu menjalani peraturan adat dan pemaknaanya yaitu upaya penyelamatkan pihak laki-laki dan perempuan. Subyek yang memaknakan pernikahan dini upaya penyelamatan yaitu: AR 
Jurnal Pendidikan Geografi:

Kajian, Teori, dan Praktik dalam Bidang Pendidikan dan Ilmu Geografi

Volume 25, Nomor 2, Jun 2020, Hal 128-144

anaknya bernama ES, MR anaknya bernama MA, YA anaknya bernama VOS, LA anaknya bernama LPA, dan MS anaknya bernama PO.

\section{KESIMPULAN}

Bedasarkan hasil penelitian yang dilakukan di Nagari Tapan, Kecamatan Basa Ampek Balai Tapan, Kabupaten Pesisir Selatan, Provinsi Sumatera Barat bahwa tindakan orang tua yang menikahkan anaknya pada usia dini memiliki banyak makna (meaning). Pemahaman makna pernikahan usia dini bagi orang tua mengacu pada pemahaman perspektif Alfred Schutz. Temuan pada studi pemaknaan pernikahan usia dini di Nagari Tapan, Kecamatan Basa Ampek Balai Tapan ditemukan dua makna pernikahan usia dini yang dilakukan oleh orang tua yaitu: 1) Pernikahan usia dini sebagai menghindar malu. 2) Pernikahan Usia Dini Sebagai Upaya Membantu Perekonomian. 3) Pernikahan Usia Dini Sebagai Upaya Penyelamatan.

\section{DAFTAR RUJUKAN}

Arimurti, I., Ira. (2017). Analisis pengetahuan perempuan terhadap perilaku melakukan pernikahan usia dini di kecamatan wonosari kabupaten bondowoso. The Indonesian Journal of Public Health, 12(2), 249-262.

Badan Pusat Statistik (BPS). (2016). Profil penduduk Indonesia hasil SUPAS 2015. Jakarta: BPS.

BKKBN. (2012). Pernikahan dini pada beberapa provinsi di Indonesia: Akar masalah \& peran kelembagaan di Daerah. Jakarta: Direktorat Analisis Dampak Kependudukuan Badan dan Keluarga Berencana Nasional.

BPS, Bappenas. (2016). Laporan analisis data perkawinan usia anak di Indonesia 2016. Jakarta: BPS, Bappenas.

Budijanto. (2011). Studi studi komparatif fertilitas penduduk antara daerah industri dan pertanian (suatu evaluasi terhadap keberhasilan program keluarga berencana pasca tahun 1998 pada masyarakat industri di Kabupaten/Kota Malang). Jurnal Pendidikan Geografi, 16(1), 1-14, http://dx.doi.org/10.17977/pg.v16i1.5539.

Creswell, J. W. (2015). Research design qualtitative and quantitative approaches. California: SAGE Publications, Inc.

Desiyanti, I. W. (2015). Factors associated with early mariage in couples of childbearing age at Kecamatan Mapanget Manado City. Jurnal Ilmu Kesehatan Muhammadiyah, 5 (2), 270-280. Retrieved from: https://ejournal.unsrat.ac.id/index.php/jikmu/article/ download/7443/6987.

Fatchan. (2013). Metode penelitian kulaitatif 10 langkah penelitian kualitatif pendekatan konstruktif dan fenomenologi. Malang: Universitas Negeri Malang Press.

Kuswarno, E. (2013). Metode penelitian komunikasi fenomenologi: konsep, pedoman, dan contoh penelitiannya. Bandung: Widya Padjajaran.

Miles, B.M \& Huberman, M. (1995). Analisis data kualitatif buku sumber tentang metode - metode baru. Jakarta: UI Press.

Montazeri, S. Gharacheh, M. (2016). Determinants of early marriage from married girls' perspectives in Iranian setting: a qualitatives study. Journal of Environmental an Public Health. Volume 2016, Article ID 8615929, $8 . \quad$ http:// dx.doi.org/10.1155/2016/8615929.

Nirmala, R. (2015). Beritagar. Tujuh alasan SDGs lebih baik dari MDGs. Retrieved from: https://beritagar.id.artikel/berita/tujuh-alasan-sdgs-lebih-baik-dari-mdgs.

Oktavia, E. R., Agustin. F. R., Magai, N. M., Widyawati, S. A., \& Cahyati, W. H. (2018). Pengetahuan risiko pernikahan dini pada remaja umur 13-19 tahun. Jurnal 
Jurnal Pendidikan Geografi:

Kajian, Teori, dan Praktik dalam Bidang Pendidikan dan Ilmu Geografi

Volume 25, Nomor 2, Jun 2020, Hal 128-144

Ilmu Kesehatan, Universitas Ngudi Waluyo, 2(2), 240. https://doi.org/10.15294/ higeia.v2i2.23031.

Oktaviani, F., Nani, D., \& Sunardi, J. (2018). Gambaran coping strategy pada remaja puteri yang melakukan pernikahan dini di Kabupaten Bandung Selatan. Jurnal Ilmiah Psikologi, 5(1), 23-42. DOI: 10.15575/psy.v5i1.2353.

Pemerintah Republik Indonesia. (1974). Undang-Undang RI Nomor 1 Pasal 7 Ayat 1 tahun 1974 tentang Perkawinan. Jakarta: Pemerintah RI.

Pohan, N.H. (2017). Faktor Yang Berhubungan dengan Pernikahan Usia Dini Terhadap Remaja Putri. Jurnal Endurance, 2(3), 424-435. DOI: http://doi.org/10.22216/ jen.v2i3.2283.

S. Livingstone and R. Das. (2010). POLIS media and family report, polis, london school of economics and political science, London, UK. Retrieved from: http:// www.researchgate.net/profile/SoniaLivingstone/publication/48910021 POLIS media and familyreport/links/5471b83e0cf24af340c3c151.pdf.

Sari, Fitri dan Sunarti, Euis. (2013). Kesiapan menikah pada dewasa muda dan pengaruhnya terhadap usia menikah. Jurnal Ilm. Kel. \& Kons. 6(3), 143-153. Retrieved from: http://journal.ipb.ac.id/index.php/jikk/article/view/9982.

Stevance, S.A. (2015). Review of Targets for the Sustainable Development Goals: The Science Perspective (online). International Council for Science (ICSU) \& International Social Science Council (ISSC).

Sukmawati. Utaya, S., \& Susilo, S. (2015). Kearifan lokal masyarakat adat dalam pelestarian hutan sebagai sumber belajar Geografi. Jurnal Pendidikan Humaniora, 3 (3), 202-208. http://dx.doi.org/10.17977/jph.v3i3.4862.

Survei Demografi dan Kesehatan Indonesia (SDKI). (2012). Situasi Keluarga Berencana di Indonesia. Jakarta.

Susilo, S. (2011). Makna remitensi TKI dalam perspektif fenomenologi. (Unpublished Dissertation). Fakultas Ilmu Sosial dan Politik, Pascasarjana. Universitas Airlangga.

Susilo, S. (2015). Fertilitas masyarakat nelayan Di Desa Banjarkemuning Kabupaten Sidoarjo. Jurnal Pendidikan Geografi, 20(2), 46-52. http://dx.doi.org/10.17977/ um017v20i22015p046.

Susilo, S. (2017). Makna pernikahan dini bagi orang tua pada masyarakat pengemis di Dusun Pelanggaran, Brata Tinggi Kecamatan Tlanakan Kabupaten Pamekasan Madura. Prosiding Seminar Nasional Tahunan Fakultas Ilmu Sosial Universitas Negeri Medan, 1(1), 472-476. Retrieved from; http://semnastafis.unimed.ac.id.

UNFPA. (2012). "From childhood to womanhood: meeting the sexual and reproductive health needs adolesent girls," Fact Sheet. Retrieved from: http://www.unfpa.org/sites/ default/files/resource-pdf/EN-SRH\%20fact\%20sheet-Adolescent.pdf.

UNFPA. (2012). Marrying too young: End child marriage. New York: UNFPA.

UNICEF. (2014). Ending child marriage: Progress and prospects. New York: UNICEF.

Yulianti, R. (2010). Dampak yang ditimbulkan akibat pernikahan dini. Pamator, 3(1), 1 5. DOI: https://doi.org/10.21107/pamator.v3i1.2394. 